\title{
The Prevalence and Nature of Terrorist Attacks in Nigeria during the Presidency of Goodluck Jonathan
}

\author{
Peculiar M. Awa \\ Correspondence: Peculiar M. Awa, Assistant Professor of Criminal Justice and Criminology, University of Central \\ Missouri, USA.
}

Received: October 27, 2020

Accepted: November 25, 2020

Online Published: November 26, 2020

doi:10.11114/ijlpa.v3i2.5090

URL: https://doi.org/10.11114/ijlpa.v3i2.5090

\begin{abstract}
During the administration of Nigerian President Goodluck Ebele Jonathan, there was a marked increase in the country's violence and frequency of terrorist attacks. The purpose of this study is to provide a descriptive analysis of terrorist incidents during the Jonathan administration. Using the START dataset, the study analyzed data over 84 months to examine the effect of Jonathan's presidency on terrorism in Nigeria. The study found a wide variation in the number of terrorist attacks between 2009 and 2015. The full presidency phase experienced a markedly more significant number of terrorist attacks than the post-presidency, acting presidency, and pre-presidency phases. On average, the full presidency and post-presidency phases experienced significantly greater rates of terrorist attacks per month than the acting presidency and pre-presidency phases. The casualty rates were consistent with this variation except that post-presidency appeared the bloodiest of all four phases. The study also revealed that Boko Haram was responsible for most terrorist attacks and casualties during the administration. Implications for these findings and recommendations for further research are discussed.
\end{abstract}

Keywords: Boko Haram, Goodluck Jonathan, Nigeria, Terrorism

\section{Introduction}

The detection and prevention of terrorist attacks have become one of the most pressing global policy priorities. An increasing number of countries are passing anti-terrorism laws and are, consequently, developing organizations, strategies, initiatives, programs, and measures to tackle terrorism effectively (Jackson, 2006). However, because terrorism has multiple causes and origins, individual rather than global approaches must be developed for nations combatting the same.

Nigeria has been identified as a country where the activities of terrorist organizations thrive (Lyman \& Morrison, 2004; Onapajo \& Uzodike, 2012; Solomon, 2012; Nsude, 2016). Despite domestic terrorism throughout the country's history, it was only during the Jonathan administration that Nigeria became internationally recognized as a country conducive to terrorist activity (Okpaga, Chijioke \& Eme, 2012; Adepoju, 2012; Nsude, 2016). This was because of the increase in terrorist incidents and the severity of such attacks during the administration (Omede, 2011; Nsude, 2016).

Goodluck Jonathan was the vice president to President Umaru Musa Yar'Adua, the $13^{\text {th }}$ president of the Federal Republic of Nigeria. On February 9, 2010, due to President Yar'Adua's poor health, the Nigerian Senate moved to make Goodluck Jonathan the acting president of the Federation. On May 5, 2010, President Yar'Adua died, and per the Nigerian Constitution, Goodluck Jonathan was sworn in as president. President Jonathan finished the remaining year in his predecessor's term and won the 2011 general elections; however, he ultimately lost the 2015 presidential election.

Jonathan's administration faced many security challenges and internal disorders, particularly terrorism (Adepoju, 2012; Chinwokwu, 2013; Maiangwa \& Agbiboa, 2014). According to the 2016 Global Terrorism Database (GTD), there were 2,888 terrorist incidents in Nigeria from January 1980 to December 2015. More specifically, 297 incidents occurred between 1980 and 2008. The vast majority of incidents (2,591) occurred from 2009 to 2015 (GTD, 2016). The severity and intensity of the terrorist attacks that rocked Nigeria from 2010 to 2015 were also unprecedented (Solomon, 2012). In fact, during the first three weeks of 2012, more than 253 people were killed in 21 attacks. An additional 900 individuals were killed due to the 164 terrorist attacks between July 2009 and January 2015. (Solomon, 2012; GTD, 2016).

A few months into the presidency (August 2011), the terrorist organization Boko Haram bombed the United Nations building in Nigeria's capital city, Abuja. Several years later, Boko Haram abducted 276 girls from the Chibok Government School (Maiangwa \& Agbiboa, 2014). As a result of the administration's failure to act, and the resulting negative press, 
terrorism in Nigeria became a matter of international concern (Onapajo \& Uzodike, 2012).

During Jonathan's administration, the primary focus of terrorist activities was the four northern states of Borno, Kano, Bauchi, and Yobe. These were the areas where Boko Haram concentrated its efforts. On May 14, 2013, due to the rise in security challenges arising from the terrorist activities of Boko Haram, President Jonathan declared a state of emergency in three northeastern states (Adamawa, Borno, and Yobe), which included two of the areas where the organization operated.

Notably, terrorism research in Nigeria is still developing and has faced some difficulty due, in part, to the government's failure to release vital information necessary to investigate the phenomenon of terrorism (Madu, 2014; Nsude, 2016). Naturally, this led to a lack of information and adequate data on terrorist incidents necessary to analyze the problem and efficiently develop counter-terrorism strategies. Additional items hindering terrorism research in the area include the illiteracy of prospective respondents, inadequacy of statistics, scanty information bases, inaccurate and lack of census figures, and insufficient funds needed to facilitate research.

As a result, research efforts into terrorism in Nigeria during the Jonathan administration have been primarily qualitative. No study has empirically analyzed the nature of the attacks during the administration. Hence, this exploratory study contributes to the literature by describing the terrorist incidents during the presidency's pendency and identifying the rate of terrorist incidents per month, the rate of casualties per month, and the perpetrators of the attacks.

In the following section, the background literature about terrorism is discussed. Afterward, the details of this exploratory study are presented, and the data source is introduced. Then, descriptive information is presented, and the significant findings are discussed. The paper concludes with recommendations for future research.

\subsection{Background}

\subsubsection{Definition of Terrorism}

Terrorism is derived from the word terror, which invokes the images of trepidation and fear. It is an act that is usually unprovoked, random, unpredictable, and intended to instill fear in the targeted victim(s). Terrorism continues to be a difficult concept to define. This is because the phenomenon is intangible and fluctuates depending on the historical and geographical contexts within which it is used. As such, terrorism, being a value-laden concept, is difficult to capture in a single definition and may be impossible to operationalize satisfactorily.

The most commonly held definition of terrorism was proffered by the United Nations in 1992 and defined terrorism as:

an anxiety-inspiring method of repeated violent action, employed by (semi-) clandestine individual, group or state actors, for idiosyncratic, criminal or political reasons, whereby - in contrast to assassination - the direct targets of violence are not the primary targets (White, 2004, p.4).

The Global Terrorism Database (GTD) (the source of the data used in this study) defines terrorism as "the threatened or actual use of illegal force and violence by a non-state actor to attain a political, economic, religious, or social goal through fear, coercion, or intimidation" (GTD, 2016, p. 9). This definition is well-rounded and includes acts such as bombings, armed assaults, and assassinations.

This paper adopts the definition of terrorism put forward by Ajayi and Adesote (2013). While evaluating the counter-terrorism attempts made by the Jonathan administration, the researchers defined terrorism as the use or threat of violence that may have limits of physical destructiveness but creates fear and shock and, as a result, high in its psychological impact. This definition was adopted because it emphasizes the descriptions of the subject matter and encompasses successful and unsuccessful terrorist attacks. It also incorporates the definition put forward by the GTD (2016).

\subsubsection{Terrorism in Nigeria}

Terrorism is not new to Nigeria. Domestic terrorism within the country has a long history (Adesoji, 2010; Adesoji, 2011; Solomon, 2012; Adeyeri, 2012). One of the earliest documented accounts of extremist events occurred in the 1980s due to the Maitatsine movement, a series of violent uprisings instigated by Islamist militants in Northern Nigeria between 1980 and 1985 (Adesoji, 2011). The movement was famous for its condemnation of Western culture, education, and technology. Its followers were young, poor, former seasonal laborers who had been economically displaced by the oil boom and petty merchants and youths seeking an Islamic education in Kano state Nigeria (Isichei, 1987; Adesoji, 2011).

Both the Southern and Northern geopolitical zones of Nigeria have experienced terrorism. Groups like the Movement for the Emancipation of the Niger Delta (MEND) in the South-South region and Boko Haram in the Northern region have posed the most significant security challenge in Nigeria (Adeyeri, 2012; Maiangwa \& Agbiboa, 2014; Nsude, 2016). These groups adopted strategies such as looting, arson, kidnapping, illegal detention, killings, and suicide bombing.

Terrorist activity has drastically increased in the last few years. After 2009, terrorism in Nigeria took a different 
direction when internal violence metamorphosed from ethnic militancy to suicide bombing and claimed over 3,000 lives; this led to the declaration of a state of emergency in three Northern states (Olalekan, 2012). With the 2011 attack of the United Nations' building in Abuja, Nigeria, the country's image was adversely affected, its impact on the international scene was undermined, and the domestic manifestation of violence within the country became a matter of global interest (Onapajo \& Uzodike, 2012). To better understand, it is essential to discuss the major terrorist organizations that have operated within Nigeria.

\subsubsection{Terrorist Organizations within Nigeria and Their Motivations}

The pattern of insecurity in Nigeria has been regionalized: militia groups in the south, the insurgency in the North, kidnapping in the East and South, ritual killings in the East and West, political and nonpolitical calculated assassinations across the nation (Ikenga \& Efebeh, 2013; Obi, 2015). The crises in the Southern region, which started in the 1990s, arising from different militant groups' activities have negatively impacted economic development in Nigeria (Nwogwugwu et al., 2012). Organizations such MEND, Movement for the Survival of the Ogoni People (MOSOP), Ijaw Youth Congress (IYC), Niger Delta Vigilante Force (NDVF), Niger Delta People's Volunteer Force (NDPVF), among others, in the Southern region, was famous for hostage-taking, kidnapping for ransom, pipeline vandalism, oil-theft, arson and ambush (Nwogwugwu et al. 2012; Adeyeri, 2012; Obi, 2015). These groups utilized kidnapping and hostage-taking to force experts involved in crude oil exploration to pressure the Nigerian government to take decisive steps towards ameliorating the environmental, social, and political problems bedeviling the area (Obi, 2015). The government (particularly the Jonathan administration) took steps to reduce the violence in the Southern regions through its amnesty programs. The militants were offered jobs, scholarships to study oil-related majors, and vocational training programs. This led to a marked reduction in violent activities in the Southern regions of Nigeria (Obi, 2015)

Additionally, religious and political clashes have rocked the Northern regions of Nigeria. However, the emergence of Boko Haram led to the metamorphoses of these clashes to full-blown terrorism. Boko Haram emerged as a radical fundamentalist Islamic sect, formed by Ustaz Mohammed Yusuf in 2002 in Maiduguri, Borno state. In 2004, the organization moved and set up a base called Afghanistan in Kanamma, Yobe state (Ikenga \& Efebeh, 2013). The sect officially calls itself "Jama'atul Alhul Sunnah Liddo' wati Wal Jihad," which means "people committed to the propagation of the prophet's teachings and Jihad" (Ikenga \& Efebeh 2013; Elden, 2014; Bamidele, 2015). Their violent activity started in 2009, and the crimes committed by this Islamic sect included: the bombing of marketplaces, churches, and government buildings, destruction of vehicles, burning of churches, police stations, schools, hospitals, clinics, army barracks, and residential houses, as well as the adoption of expatriates.

Another major insecurity challenge facing Nigeria involves the activities of the Fulani herdsmen. The Fulani Militants are not members of one group, but they are nomads traveling from city to city on foot to graze their livestock (Obi, 2015). In their travels, they frequently trespass farmlands owned by locals in their host communities, destroying crops and valuables. Attempts by farmers to prevent the destruction of their properties lead to death, injury, and eviction from their homes due to the stiff and violent resistance from the Fulani herdsmen. There have also been allegations to the effect that the herdsmen take advantage of these opportunities to steal, raze houses, rape, and kill innocent members of the communities they pass through (Chilaka \& Odoh, 2012; Obi, 2015).

Furthermore, it is unknown if the individual attacks by the Fulani Militants are related. It has also been contested that these attacks could be related to the activities of other terrorist groups. Many argue that they may be Boko Haram members passing off as Fulani herdsmen. Others (including the Nigerian military) posit that they are herdsmen from other parts of West Africa and not Fulani (Akinola, \& Tella, 2013; Awoniyi, 2013). While the latter may be plausible due to porous Nigerian borders and inadequate immigration surveillance, it is challenging to correlate Boko Haram terrorists' activities to those of the Fulani herdsmen (Akinola, \& Tella, 2013; Awoniyi, 2013). Boko Haram has utilized explosives carried by suicide bombers or hidden in a target. However, accounts by victims of the herdsmen crisis have shown that the Fulani militants' primary interest is to gain greater access to grazing lands for their livestock (Chilaka \& Odoh, 2012; Akinola, \& Tella, 2013; Awoniyi, 2013; Obi, 2015).

\subsubsection{Causes of Terrorism in Nigeria}

The politicization of religion has played a significant role in the evolution of terrorist activity in Nigeria. The Northern region has been a fertile ground for religious activism traced to the Jihad of Uthman Dan Fodio in the early $18^{\text {th }}$ century (Ajayi, 1990). Scholars state that the ruling elite's unwillingness to separate politics and religion drives the country's proliferation of violence (Ajayi, 1990; Onapajo \& Uzodike, 2012; David, 2013; Nsude, 2016). According to Ajayi (1990), because the ruling elite derives legitimacy from religion and not the people, they frequently use religion as a political weapon to mobilize the masses and divert attention from their ineptitude, corruption, and incompetence. This issue is not unique to the Northern region or Islamists. The ruling elites in the Southern region, predominantly Christian, also patronize Christianity for selfish gains (Ajayi, 1990). However, the situation is more evident in the North because it 
is relatively monolithic due to the rise of Jihad in Nigeria and the after-effects of colonialization (Ajayi, 1990; Solomon, 2012; David, 2013; Elden, 2014).

It is essential to approach the subject matter of the institutionalization of terrorism in Nigeria from socio-economic instability. This is closely linked to colonialism's effects, the barriers to the criminalization of terrorism, and the negative rewards system within Nigeria (Yahaya, 2015). This approach is vital because it explains terrorism by capturing the present fundamental issues while addressing its history. It also recognizes previous counter-terrorism efforts that evolved into factors that encouraged the proliferation of terrorism in Nigeria (Yahaya, 2015).

Furthermore, it is not coincidental that the worst forms of political violence in present-day Nigeria emanate from socio-economically deprived areas (Agbiboa, 2014). The states of the Northern part of the country where poverty is so high, and unemployment is rife hosts radical Islamist groups that have challenged the government's authority. For example, Boko Haram enticed impoverished youth and their families with promises of financial remuneration. Approximately $\$ 150.00$ (U.S.) was given to the radicalized individual's family in exchange for becoming a suicide bomber (Nsude, 2016). The youth were so impoverished that they were willing to quickly become radicalized and sacrifice their lives for a mere $\$ 150.00$. For someone in the Western world, $\$ 150.00$ may be insignificant; however, this is a substantial sum of money for people in third-world countries. As seen above, the combination and manipulation of religion, poverty, and politics are potent factors that facilitate the proliferation of terrorism in Nigeria (Ajayi, 1990; Elden, 2014; Nsude, 2016).

\subsection{The Uniqueness of Goodluck Jonathan's Administration and Its Correlation to Terrorism in Nigeria}

With this evolution in Boko Haram's tactics, the organization gained international attention marked by a shift from local grievances deeply rooted in cultural and religious clashes existing in Nigeria to attacking international targets. Boko Haram's initial geographical focus was the four northern states of Borno, Kano, Bauchi, and Yobe. However, counter-terrorism activities used by the Nigerian government (particularly the Jonathan administration) led to an increase in the organization's attacks on targets within and outside its traditional areas of operation (Bloom \& Matfess, 2016). In 2011, the organization began targeting the military, the police, and other organizations affiliated with the state.

When Boko Haram was first formed in 2002, their actions were nonviolent. Beginning in 2009, shortly before the beginning of Jonathan's presidency, their activities became more violent. 2009-2015 symbolizes the most violent phase of domestic terrorism in Nigeria, mainly attributable to Boko Haram. By 2015, the organization's 6-year insurgency had killed 20,000 and forced 2.3 million people to flee their homes (Steward, 2015).

Since 2013, Boko Haram has significantly contributed to gendered violence against women (Osita-Njoku \& Chikere, 2015). Scholars have attributed the reason behind the rise in the abduction and use of women by Boko Haram to the declaration of the state of emergency by the Jonathan administration in May 2013 (Zenn \& Pearson, 2014; Bloom \& Matfess, 2016). Onuoha \& George (2015) contend that the use of kidnapping as a tactic by the sect began after a raid by federal forces led to the arrest of family members of suspected sect members and over a hundred women, including the wives of Abubakar Shekau, the new leader of Boko Haram (Barkindo, Gudaku, \& Wesley, 2013). As a result, a threat was issued by the group leader in January 2014 to engage in a gender-based abduction centered mainly on the kidnapping of women (Maiangwa and Amao, 2015). Subsequently, the victimization of women and Gender-Based Violence (GBV) became an overt aspect of the Boko Haram activities in the North-Eastern region of Nigeria (Zenn and Pearson, 2014; Human Rights Watch, 2014; Maiangwa and Amao, 2015).

The year 2013 marked the beginning of Boko Haram's tactic to use women and girls. After a series of kidnappings, female participation in the group's activities significantly increased. The 2014 kidnapping of 276 schoolgirls signified the group's strategic focus on kidnapping women and girls in North-Eastern Nigeria (Bloom \& Matfess, 2016). This incident and the failure of Jonathan's administration to rescue the kidnapped schoolgirls stirred up a global outcry and led to an increased public awareness of violence against women and girls in Nigeria. However, this global awareness also inspired Boko Haram to begin deploying women as suicide bombers in the bid to gain notoriety through the shock and awe tactic of terrorism (Onuoha \& George 2015; Bloom \& Matfess, 2016).

Boko Haram continues to kidnap women and girls. The sect has used more women and girls in their bombing attacks than any other terrorist organization in history (Bloom \& Matfess, 2016). Between June 2014 and January 2015, Boko Haram carried out 89 attacks against civilian soft targets, in which they used women or girls (Bloom \& Matfess, 2016). The organization has deployed approximately 244 female suicide bombers since 2014 (Aziz, 2017). While terrorist organizations in other countries (e.g., Sri Lanka) and regions (e.g., Middle East) have employed female operatives, Boko Haram's use of women and girls has been even greater and unprecedented in scale. For example, throughout its ten-year history, the Tamil Tigers utilized 46 women, while Boko Haram deployed more than 90 women and girls in 18 months, from June 2014 to December 2015 (Steward, 2015; Bloom \& Matfess, 2016). The active involvement of women in Boko Haram's activities as logistics or support personnel, attackers, and martyrs has grown to substantially 
become a matter of public attention across the globe (Sjoberg et al., 2011). This aspect of terrorism represents a novel but a growing trend (Maiangwa and Amao, 2015; Bloom \& Matfess, 2016).

\section{The Present Study}

This study explored terrorist incidents during the presidency of Goodluck Jonathan. More specifically, the purpose of this study was to provide a descriptive analysis of terrorist incidents during the Jonathan administration to identify the rate of terrorist incidents per month, the rate of casualties per month, and the perpetrators of these attacks.

The primary research question is: How did the timing of the presidency impact terrorist attacks, as measured by (1) rate of terrorist attacks per month; (2) rate of people killed due to these attacks per month; and (3) rate of people wounded due to these attacks per month. Secondary questions included the following:

1. What was the geographical distribution of terrorist attacks during the Jonathan administration?

2. Was Boko Haram majorly responsible for the terrorist incidents that occurred during the Jonathan administration?

From the perusal of available literature and data on terrorist incidents in Nigeria, I propose three hypotheses. First, I hypothesized that the Jonathan administration led to more terrorist incidents and increases in casualties. Secondly, I hypothesized that the Northern regions of Nigeria accounted for most terrorist incidents and casualties during the Jonathan administration. Lastly, I hypothesized that Boko Haram was primarily responsible for terrorist incidents during the Jonathan administration.

The study period was from January 2009 to December 2015 and covered fourteen months before Goodluck Jonathan took over his predecessor's term, the duration of his full presidency, and seven months after his administration ended. The available data used in this study ended in December 2015. For this reason, data beyond December 2015 could not be analyzed.

The data and methods are described in the following sections.

\subsection{Data}

The data used in this study was obtained from the Global Terrorism Database (GTD) made available by the National Consortium for the Study of Terrorism and Responses to Terrorism (START) at the University of Maryland. This study represents 84 months of all terrorist attacks in Nigeria.

\section{Dependent Variables}

The study explored three dependent variables of importance.

Dependent variable 1: 2,591 attacks - rate per month

Dependent variable 2: 17,522 killed - rate per month

Dependent variable 3: 7,503 wounded - rate per month

The rates were derived by dividing each dependent variable's total number by the number of months in the individual phases of interest.

\section{Independent Variable:}

The independent variable is the "timing of terrorist incidents" during the study period. This ordinal level variable was recoded into four variables: pre-presidency (14 months before President Jonathan took-over his predecessor's term), acting presidency (after he took over his predecessor's term-14 months), full presidency (49 months after the 2011 general elections), and post-presidency (7 months after Jonathan's administration). Comparing these phases is essential to determine if the Jonathan administration was associated with higher rates of terrorist attacks and casualties.

\section{Additional Independent Variables}

The study explored the relationships of several variables with the dependent variables during the Jonathan administration. The extraneous variables used in the study include the location of the incident and the organization responsible. Location was recoded into six classifications representing the six geopolitical zones in Nigeria: (1) North Central, (2) North East, (3) North West, (4) South East, (5) South South, and (6) South West regions. The organization responsible, which had 23 categories in the dataset ${ }^{\mathrm{i}}$, was recoded into six categories: (1) Boko Haram, (2) MEND, (3) Fulani Militants, (4) Tribal Militias, (5) "other" (which included organizations with less than ten terrorist acts), and (6) "unknown." 


\subsection{Analytical Framework}

An exploratory, descriptive research design was used for this study. I began with a descriptive analysis of the data, overall and for each of the four categories of the dependent variable - timing of terrorist incidents. Then, I analyzed the data to determine the rate of terrorist attacks per month by timing, terrorist organization, and region. The data was also analyzed to determine the rate of casualties (including killed and wounded) by timing, terrorist organization, and region. Last, I ran a one-way ANOVA to compare (1) average attacks and (b) average casualties across the four phases of interest.

\section{Results}

Figure 1 below shows a line chart of the incidents of terrorist attacks over the 84 months of interest

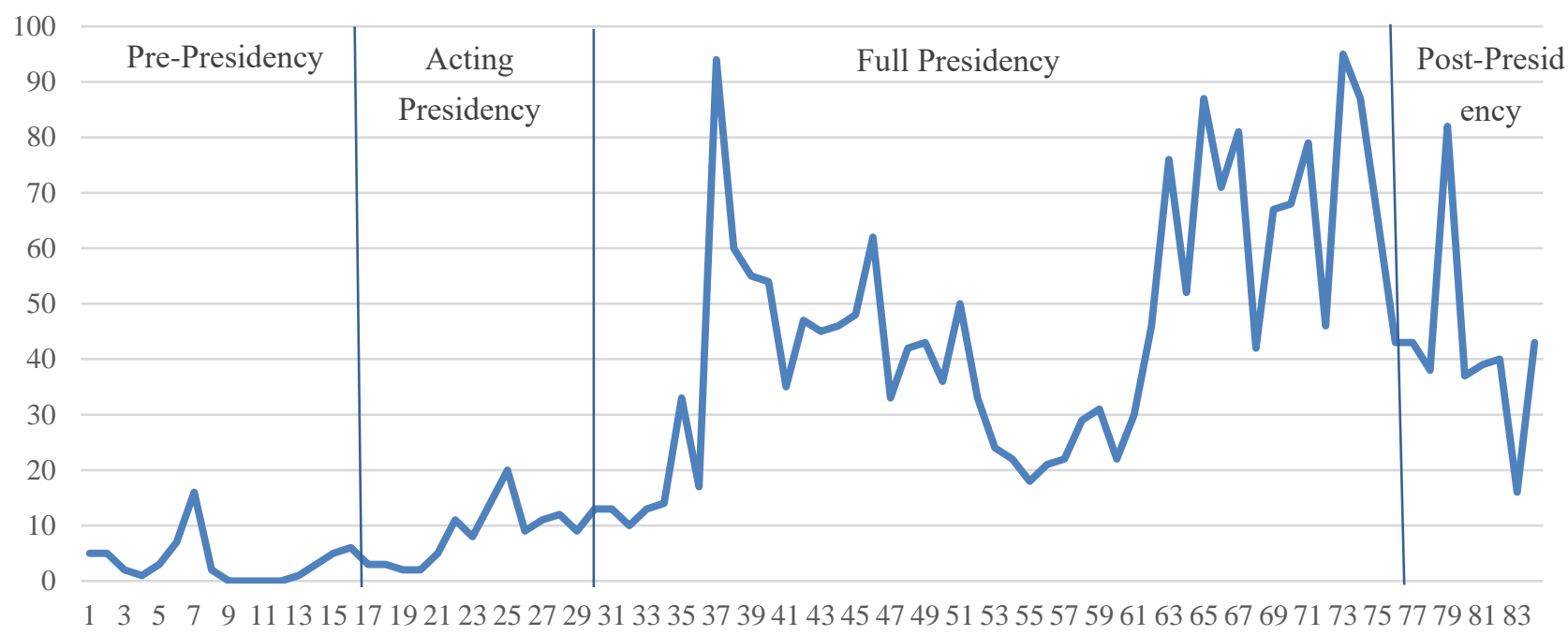

Figure 1. Number of Recorded Terrorist Incidents in Nigeria during the Four Phases of Interest (2009-2015)

Data shows a wide variation in the number of terrorist attacks between 2009 and 2015 ( 84 months). The full presidency phase $(N=2,126)$ experienced a markedly more significant number of terrorist attacks than the post-presidency $(N=302)$, acting presidency $(N=106)$, and pre-presidency $(N=57)$ phases. Table 1 below shows the number of terrorist attacks per month on average by timing, terrorist organization, and region. 
Table 1. Rate of Terrorist Attacks per Month by Timing, Terrorist Organization, and Region (N=84 Months, January 2009- December 2015)

\begin{tabular}{|c|c|c|c|c|c|c|c|}
\hline \multirow[b]{2}{*}{ Timing } & \multirow[b]{2}{*}{ Terrorist Organization } & \multicolumn{6}{|l|}{ Region } \\
\hline & & $\begin{array}{l}\text { North } \\
\text { Central }\end{array}$ & $\begin{array}{l}\text { North } \\
\text { East }\end{array}$ & $\begin{array}{l}\text { North } \\
\text { West }\end{array}$ & $\begin{array}{l}\text { South } \\
\text { East }\end{array}$ & $\begin{array}{l}\text { South } \\
\text { South }\end{array}$ & $\begin{array}{l}\text { South } \\
\text { West }\end{array}$ \\
\hline \multirow{7}{*}{$\begin{array}{l}\text { Pre-presidency } \\
\text { (14 months) }\end{array}$} & Boko Haram & - & 0.71 & - & - & - & - \\
\hline & MEND & - & - & - & - & 1.29 & 0.07 \\
\hline & Fulani Militants & 0.07 & - & - & - & - & - \\
\hline & Tribal Militants & - & - & - & - & 0.07 & - \\
\hline & Others & - & - & - & - & 0.43 & 0.07 \\
\hline & Unknown & 0.07 & & 0.07 & 0.07 & 1.00 & 0.14 \\
\hline & Total & 0.14 & 0.71 & 0.07 & 0.07 & 2.79 & 0.28 \\
\hline \multirow{7}{*}{$\begin{array}{l}\text { Acting } \\
\text { Presidency } \\
\text { (14 months) }\end{array}$} & Boko Haram & 0.21 & 2.86 & - & - & - & - \\
\hline & MEND & 0.14 & - & - & - & 0.29 & 0.07 \\
\hline & Fulani Militants & 0.07 & - & 0.07 & - & - & - \\
\hline & Tribal Militants & - & - & - & - & - & - \\
\hline & Others & - & - & 0.07 & - & 0.28 & - \\
\hline & Unknown & 1.07 & 0.64 & 0.21 & 0.29 & 1.21 & 0.07 \\
\hline & Total & 1.49 & 3.50 & 0.35 & 0.29 & 1.78 & 0.14 \\
\hline \multirow{7}{*}{$\begin{array}{l}\text { Full presidency } \\
\text { ( } 49 \text { months) }\end{array}$} & Boko Haram & 1.12 & 23.0 & 3.41 & 0.04 & 0.02 & 0.12 \\
\hline & MEND & 0.02 & - & - & - & 0.27 & - \\
\hline & Fulani Militants & 3.49 & 0.57 & 1.00 & - & 0.02 & - \\
\hline & Tribal Militants & 0.08 & - & - & 0.04 & 0.04 & 0.02 \\
\hline & Others & 0.02 & 0.1 & 0.12 & 0.04 & - & 0.02 \\
\hline & Unknown & 2.00 & 2.84 & 1.65 & 0.55 & 2.20 & 0.35 \\
\hline & Total & 6.73 & 26.51 & 6.18 & 0.67 & 2.55 & 0.51 \\
\hline \multirow{7}{*}{$\begin{array}{l}\text { Post-presidency } \\
\text { ( } 7 \text { months) }\end{array}$} & Boko Haram & 1.00 & 30.14 & 0.86 & - & - & - \\
\hline & MEND & - & - & - & - & - & - \\
\hline & Fulani Militants & 1.86 & 0.29 & - & - & - & 0.14 \\
\hline & Tribal Militants & 0.14 & - & - & - & 0.14 & - \\
\hline & Others & - & - & 0.14 & - & - & - \\
\hline & Unknown & 1.57 & 2.00 & 1.14 & 0.29 & 2.86 & 0.43 \\
\hline & Total & 4.57 & 32.43 & 2.14 & 0.29 & 3.00 & 0.57 \\
\hline
\end{tabular}

A visual inspection of Table 1 shows that MEND was responsible for a rate of 1.36 terrorist attacks per month during the pre-presidency phase. Terrorist activities of the organization began to decrease during the acting presidency (rate= 0.5 ) and full presidency (rate $=0.29$ ) phases until it entirely disappeared during the post-presidency phase. The activities of Fulani Militants were at their highest during the full presidency phase (rate= 5.08). Most importantly, Boko Haram became the force responsible for the majority of the terrorist attacks during the acting presidency (rate $=3.07$ ), full presidency (rate $=27.71$ ), and post-presidency phases (rate $=32$ ). The activities of Boko Haram drastically increased in all the regions with a marked rise in the North East region.

Furthermore, the data were also analyzed to determine the rate of casualties (including the number of people killed and wounded) by timing, terrorist organization, and location during the study period. This is contained in Table 2 below. 
Table 2. Rate of Casualties (Including Killed and Wounded) by Timing, Terrorist Organization, and Region $(\mathrm{N}=84$ Months, January 2009- December 2015)

\begin{tabular}{|c|c|c|c|c|c|c|c|}
\hline \multirow[b]{2}{*}{ Timing } & \multirow{2}{*}{$\begin{array}{l}\text { Terrorist } \\
\text { Organization }\end{array}$} & \multicolumn{6}{|l|}{ Region } \\
\hline & & $\begin{array}{l}\text { North } \\
\text { Central }\end{array}$ & $\begin{array}{l}\text { North } \\
\text { East }\end{array}$ & $\begin{array}{l}\text { North } \\
\text { West }\end{array}$ & $\begin{array}{l}\text { South } \\
\text { East }\end{array}$ & $\begin{array}{l}\text { South } \\
\text { South }\end{array}$ & $\begin{array}{l}\text { South } \\
\text { West }\end{array}$ \\
\hline \multirow{7}{*}{$\begin{array}{l}\text { Pre-presidency } \\
\text { (14 months) }\end{array}$} & Boko Haram & - & 21.71 & - & - & - & - \\
\hline & MEND & - & - & - & - & 1.42 & 0.35 \\
\hline & Fulani Militants & - & 0 & - & - & - & - \\
\hline & Tribal Militants & - & - & - & - & 0 & - \\
\hline & Others & - & - & - & - & 0 & 0 \\
\hline & Unknown & 0 & - & 0 & 0 & 0.28 & 0.35 \\
\hline & Total & 0 & 21.71 & 0 & 0 & 1.7 & 0.7 \\
\hline \multirow{7}{*}{$\begin{array}{l}\text { Acting } \\
\text { Presidency } \\
\text { (14 months })\end{array}$} & Boko Haram & 10.6 & 10.2 & - & - & - & - \\
\hline & MEND & 3.64 & - & - & - & 0 & 0 \\
\hline & Fulani Militants & 0.07 & - & 0.07 & - & - & - \\
\hline & Tribal Militants & - & - & - & - & - & - \\
\hline & Others & - & - & 0.07 & - & 0 & - \\
\hline & Unknown & 9.71 & 6.07 & 0.21 & 0.35 & 1.71 & 0.35 \\
\hline & Total & 24.02 & 16.27 & 0.35 & 0.35 & 1.71 & 0.35 \\
\hline \multirow{7}{*}{$\begin{array}{l}\text { Full presidency } \\
\text { (49 months) }\end{array}$} & Boko Haram & 23.0 & 256.71 & 38.28 & 0 & 0 & 0.18 \\
\hline & MEND & 0 & - & - & - & 1.30 & - \\
\hline & Fulani Militants & 21.57 & 12.63 & 11.69 & - & 0.02 & - \\
\hline & Tribal Militants & 1.03 & - & - & 0.16 & 0 & 0.04 \\
\hline & Others & 0.14 & 0.2 & 0.44 & 0.02 & - & 0.02 \\
\hline & Unknown & 7.36 & 10.63 & 4.69 & 0.4 & 3.4 & 0.3 \\
\hline & Total & 53.1 & 280.17 & 55.1 & 0.58 & 4.72 & 0.54 \\
\hline \multirow{7}{*}{$\begin{array}{l}\text { Post-presidency } \\
\text { ( } 7 \text { months) }\end{array}$} & Boko Haram & 26.14 & 544.7 & 42.14 & - & - & - \\
\hline & MEND & - & - & - & - & - & - \\
\hline & Fulani Militants & 10.85 & 2 & - & - & - & 0 \\
\hline & Tribal Militants & 0.28 & - & - & - & 0 & - \\
\hline & Others & - & - & 1 & - & - & - \\
\hline & Unknown & 6.85 & 15.28 & 15.71 & 0 & 8.42 & 0.14 \\
\hline & Total & 44.12 & 561.98 & 16.71 & 0 & 8.42 & 0.14 \\
\hline
\end{tabular}

Note: "-" means no incident, while "0" means there was a terrorist attack but no casualty.

A visual inspection of Table 2 shows that the North East region (rate $=562$ ) had the highest rate of casualties per month. Further inspection of Table 2 also shows that at every phase, the activities of Boko Haram resulted in the highest rate of casualties per month (pre-presidency, rate= 21.71; acting presidency, rate= 20.8; full presidency, rate= 316; post-presidency, rate $=613$ ). The post-presidency phase experienced a marked increase in the rate of casualties resulting from the activities of Boko Haram.

In Figure 2 below, line charts of the means of terrorist attacks, people killed and wounded over the 84 months of interest is shown. 

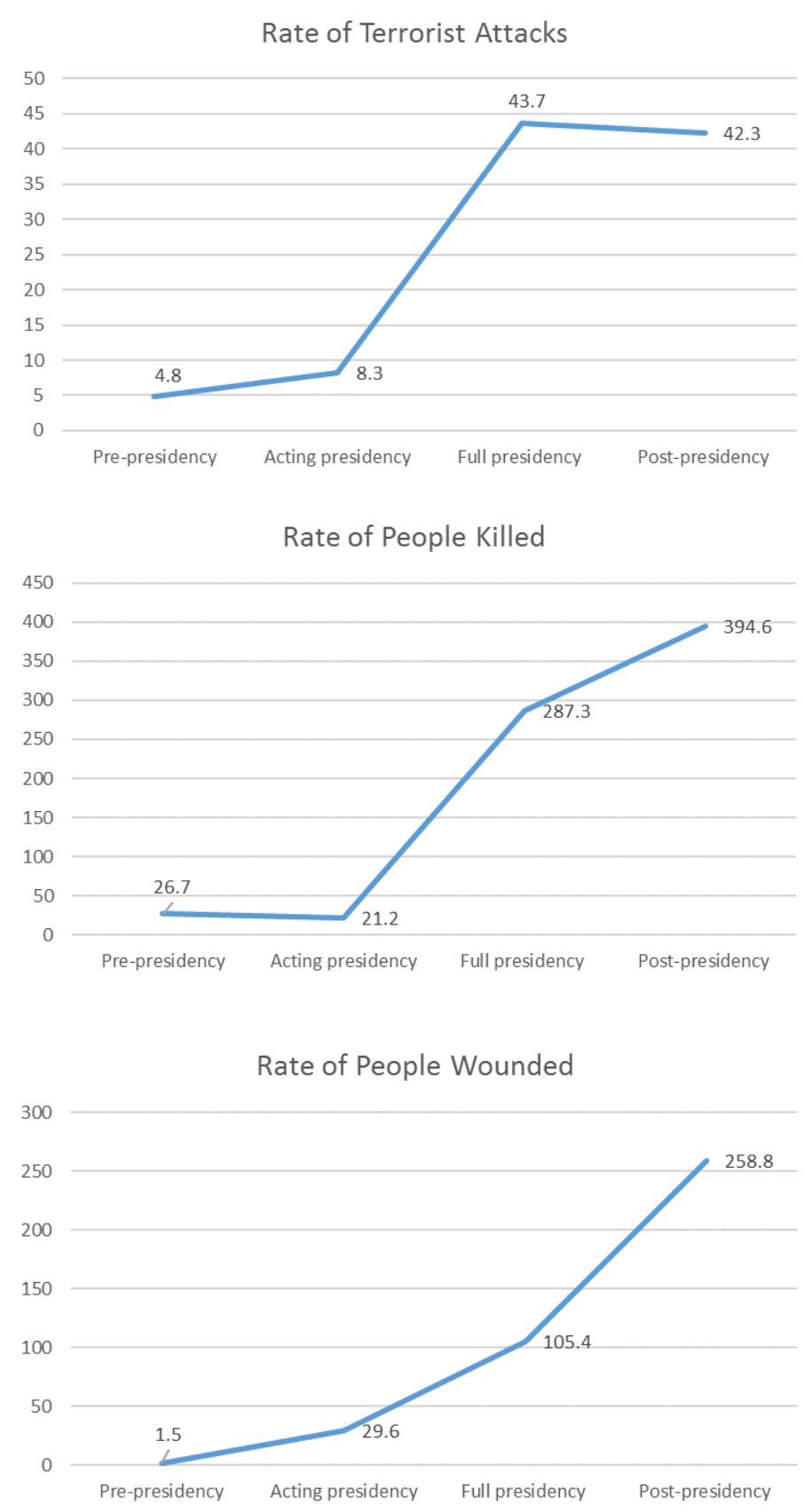

Figure 2. Rate of Terrorist Attacks, People Killed and Wounded during the Study Period (N= 84 months, 2009- 2015)

On average, full presidency $(\mu=43.67)$ and post-presidency $(\mu=42.25)$ experienced markedly greater rates of terrorist attacks per month than the acting presidency $(\mu=8.33)$ and pre-presidency phases $(\mu=4.75, F=20.96 ; p<.001)$. The rates of people killed per month were consistent with this variation except that post-presidency phase appeared to be the bloodiest of the four phases $(\mu=394.63$; full presidency, $\mu=287.31$; pre-presidency, $\mu=26.67$; acting presidency, $\mu=21.17, F=7.43 ; p<.001$ ). Finally, on average, there were two and half times more people wounded per month during post-presidency than full presidency $(\mu=258.75$; full presidency, $\mu=105.41$; pre-presidency, $\mu=1.50$; acting presidency, $\mu=29.58, F=14.13 ; p<.001$ ). While terrorist attacks decreased in frequency since the post-presidency, their lethal nature increased drastically, suggesting fewer but much deadlier attacks. 


\section{Discussion}

I analyzed data to determine the distribution of terrorist attacks, as measured by the rate of terrorist attacks per month, the rate of casualties (including the number of people killed and wounded) per month, and the perpetrators of these attacks during the Jonathan administration. A one-way analysis of variance (ANOVA) was conducted to determine whether there were any statistically significant differences between the attack rates, rates of people killed, and the rates of people wounded across the four phases of interest.

\subsection{Overview of Findings}

The results of the overall descriptive analysis of the data indicate some key findings. First, there was a wide variety of attacks over the periods evaluated with different terrorist groups active at each phase. Second, there was an uptick in the number of terrorist organizations active and not only the severity of attacks. Lastly, there were clear regional trends in the attacks that occurred. Each of these significant results is discussed below.

Results from the current study revealed several important issues that warrant discussion. First, the findings indicate that MEND's activities, which were responsible for the highest attack rate per month during the pre-presidency phase, began to decrease during the acting presidency and full presidency phases until it entirely disappeared in the post-presidency phase. This is an exciting finding because the decline in MEND's activities could have been due to the Jonathan administration's amnesty program (Obi, 2015).

During the full presidency phase of the Jonathan administration, unknown organizations accounted for a rate of 9.59 terrorist incidents per month. This finding was unanticipated because qualitative research indicates that Boko Haram's activities during the full presidency phase were responsible for increasing national media attention during the study period (Olalekan, 2012; Onapajo \& Uzodike, 2012; Elden, 2014; Agbiboa, 2014). It is also possible that these activities could have been perpetrated by Boko Haram or other known terrorist organizations.

Data showed that the Northern regions accounted for the majority of terrorist attacks and casualties during the study period. During the full presidency and post-presidency phases, Boko Haram was responsible for most casualties that resulted from terrorist activities in the Northern regions. Boko Haram's activities and the resultant casualties further increased during the post-administration phase (by approximately seven incidents and 288 casualties per month). This finding was somewhat inconsistent with previous research, which suggested that the most violent phase of the activities of Boko Haram was during the Jonathan administration (Onapajo \& Uzodike, 2012; Agbiboa, 2014; Elden, 2014; Madu, 2014; Bamidele, 2015). Consequently, the question remains whether the sizeable observed increase in terrorist acts during the study period, as depicted in Figure 1, resulted from the change in leadership and the Jonathan administration or a preexisting upward trend. This point is further buttressed because while terrorist attacks decreased in frequency since the post-presidency, their lethality increased significantly.

The question that begs to answer is: What other factors could have led to an increase in the rate of terrorist activity and casualties throughout the Jonathan administration? I offer a few conjectures that warrant discussion. One possibility is that Boko Haram's activities in Northern Nigeria could have been responsible for the overall rise in terrorist incidents during the study period. A highly violent terrorist act might receive considerable media coverage and motivate the organization's activities to escalate. Consistent with this assertion is the finding that Northern Nigeria accounted for a vast majority of the terrorist incidents during the study period. Also, Boko Haram was responsible for the majority of the terrorist attacks and resultant casualty rates during the study period. This means that the activities of Boko Haram could have led to the increased media attention on Nigeria during the study period.

Terrorism in Nigeria received international attention because of the rise of Boko Haram, which officially began in July 2009 in the Northern part of the nation (Agbiboa, 2014). The international community was mainly concerned with the effectiveness of the Jonathan administration in handling the security threats of violence in Nigeria (Madu, 2014). The ideological motivations of Boko Haram are primarily influenced by the transformation from local Salafism ${ }^{\text {ii }}$ to international jihadism (Zenn, Barkindo, \& Heras, 2013). Scholars suggest that Boko Haram metamorphosed into a terrorist group in 2010 when they pledged allegiance to Al Qaeda (Agbiboa, 2014; Madu, 2014; Bamidele, 2015). This was around the same period that President Jonathan took over his predecessor's term. Was this a mere coincidence, or could there have been some political undertones to the evolution of Boko Haram? This is an area upon which future research can build.

A second explanation for my findings concerns the relationship between the geographical location of terrorist attacks and the overall prevalence and nature of terrorist incidents in Nigeria. This study's findings reveal that the majority of the terrorist incidents during the study period occurred in Northern Nigeria. Investigating to determine if these states house terrorists because of the ideology that they are fighting against the government or are too poor and cannot extradite them would advance the research. Analyzing the subject-matter by the different geopolitical zones in Nigeria may yield 
more results towards understanding the nature of terrorism within the country. Accordingly, it would be beneficial to investigate further which factors make these areas more susceptible to terrorist attacks.

Additionally, the current study revealed that the most violent phase of the terrorist incidents during the study period occurred during the full presidency and post-presidency phases. It is unclear, however, if the operationalization of terrorism played any role in this regard. The heightened international attention to terrorist attacks in Nigeria due to Boko Haram's activities may have resulted in more significant reporting of individual incidents; therefore, the increase in incidents during this period may not necessarily represent more attacks. The events of September 11, 2001, made terrorism real for Americans and the Western world, in general, because it happened on American soil. It brought international attention to a topic that was not new to many people around the globe. The 2011 bombing of the UN headquarters in Nigeria by Boko Haram also brought considerable attention to Nigeria. This may be because the operationalization of terrorism is a matter of perception and plays a role in determining what acts are considered terrorism or otherwise. The heightened awareness could account for the increase in the observation of terrorism in Nigeria and around the world.

A third explanation pertains to the effect of the socio-economic factors that abound in Nigeria on the propensity to host violence. Studies that have emphasized this fact suggest that socio-economic deprivation in Northern Nigeria facilitates religious extremism and terrorism. (Solomon, 2012; Agbiboa, 2014; David, 2013; Elden, 2014; Yahaya, 2015). Based on these claims, one can hypothesize a correlation between religion, demographics, geography, and the prevalence and nature of terrorism in Nigeria.

Finally, the qualitative details provided by researchers also attest to the destructive nature of terrorism in Nigeria. The current work established a link between terrorist incidents, timing, and location. Indeed, the varying location of Nigerian terrorist incidents may simply result from geopolitical shifts of power. Consistent with these findings is the assertion that demographics and geography play significant roles in the proliferation of terrorist incidents in Nigeria. Although such consideration is beyond the scope of this current study, it warrants future investigation.-

\section{Conclusion}

A sizable body of qualitative research on the effect of the Jonathan administration on Nigeria's security challenges has accrued in recent years. A common feature of these studies is the perception that the Jonathan administration, beginning with the completion of his predecessor's term, had an immediate, continuous, positive effect on the incidents of terrorism. Using data obtained from the GTD, the current study attempted to incrementally add to the understanding of the prevalence and nature of the terrorist incidents during the Jonathan administration.

I hypothesized that the Jonathan administration led to more terrorist incidents and increases in casualties. In support of this hypothesis, my analysis revealed that the full presidency phase experienced a markedly greater number of terrorist attacks than the pre-presidency, acting presidency, and post-presidency phases. The rates of casualties (including people killed and wounded) were consistent with the variation in terrorist attacks by phases except that the post-presidency appeared the bloodiest phase of the four. These findings suggest that while terrorist attacks decreased in frequency since the post-presidency, their lethality increased considerably. The findings of this study suggest that other factors exist that contributed to the frequency of terrorist activities. This is an area upon which future research can build.

Furthermore, I hypothesized that the Northern regions accounted for the majority of terrorist incidents and casualties. I also hypothesized that Boko Haram was primarily responsible for the terrorist incidents and resultant casualties during the Jonathan administration. The study's findings indicate that beginning with the acting presidency to the full presidency and post-administration phases, Boko Haram was responsible for the vast majority of the terrorist attacks and caused the most casualties. During the full presidency and post-presidency phases, terrorist attacks increased in the Northern regions of the country. These findings suggest that geographical factors play significant roles in predicting the prevalence of terrorist activity in Nigeria. It is unequivocally clear that demographics and geography should be considered when analyzing the prevalence and nature of terrorist incidents in Nigeria.

There is still a debate regarding the factors that facilitate the proliferation of terrorism in regions where terrorism thrives. An analysis of the terrorist incidents during the Jonathan administration in Nigeria reveals that the influence of location on the timing and nature of terrorism in the country seems to be a promising avenue for future research. Despite my findings, the effect of the Jonathan administration on the incidents of terrorism in Nigeria is likely to remain of interest to both policymakers and scholars. This is an important question that is frequently raised, with little empirical evidence to base definitive answers. This study aimed to provide an empirical analysis of the prevalence and nature of terrorist incidents during the Jonathan administration. The findings presented in the current study constitute building blocks for a deepened understanding of the prevalence and nature of terrorism in Nigeria. Today, violence in Nigeria, mainly due to Boko Haram's activities, is still a significant concern even beyond the Jonathan administration. Empirical analysis that studies the nature of these incidents post the Jonathan administration would benefit the literature. 


\section{References}

Adesoji, A. O. (2010). The Boko Haram uprising and Islamic revivalism in Nigeria. Africa Spectrum, 45(2), 95-108. https://doi.org/10.1177/000203971004500205

Adesoji, A. O. (2011). Between Maitatsine and Boko Haram: Islamic fundamentalism and the response of the Nigerian State. Africa Today, 57(4), 98-119. https://doi.org/10.2979/africatoday.57.4.99

Adepoju, O. (2012). What is the source of Boko Haram's sophisticated military and propaganda strategy? Journal of Religion in Africa, 15(4), 145-188.

Adeyeri, O. (2012). Nigerian state and the management of oil minority conflicts in the Niger Delta: A retrospective view. African Journal of Political Science and International Relations, 6(5), 97-103. https://doi.org/10.5897/AJPSIR11.097

Agbiboa, D. E. (2014). Peace at daggers drawn? Boko Haram and the state of emergency in Nigeria. Studies in Conflict \& Terrorism, 37(1), 41-67. https://doi.org/10.1080/1057610X.2014.853602

Ajayi, G. (1990). Government and religious patronage in contemporary Nigeria (1980-1989): Implications for the stability of the nation. Zeitschrift fur Afrika Studies (ZAST) 7/8, 55-65.

Ajayi, A. I., \& Adesote, A. S. (2013). The gains and pains of the amnesty programme in the Niger Delta region of Nigeria, 2007-2012: A preliminary assessment. Journal of Asian and African Studies, 48(4), 506-520. https://doi.org/10.1177/0021909613493607

Akinola, A. O., \& Tella, O. (2013). Boko Haram terrorism and Nigeria's security dilemma: Rethinking the state's capacity. International Journal of Innovative Social Sciences and Humanities Research, 1, 3.

Awoniyi, S. (2013). A Discourse on religious conflict and tolerance in multi-faith Nigeria. European Scientific Journal, ESJ, 9(20).

Aziz, S. F. (2017). Losing the War of Ideas: A Critique of Countering Violent Extremism Programs. Tex. Int'l LJ, 52, 255.

Bamidele, O. (2015). Combating terrorism: Anti-terrorism law, Boko Haram and insecurity in Nigeria. African Journal of Democracy and Governance, 2(34), 139-158.

Barkindo, A., Gudaku, B. T., \& Wesley, C. K. (2013). Boko Haram and gender-based violence against christian women and children in north-eastern Nigeria since 1999. NPV RN working paper No. 1 (Amsterdam: Open Doors International).

Bloom, M., \& Matfess, H. (2016). Women as Symbols and Swords in Boko Haram's Terror. Prism: a Journal of the Center for Complex Operations, 6(1), 104.

Chilaka, F. C., \& Odoh, S. I. (2012). Climate change and conflict in Nigeria: A theoretical and empirical examination of the worsening incidence of conflict between Fulani herdsmen and farmers in northern Nigeria. Oman Chapter of Arabian Journal of Business and Management Review, 2(1), 110-124. https://doi.org/10.12816/0002246

Chinwokwu, E. C. (2013). The challenges of conflict management in a democratic society: An overview of insecurity in Nigeria. American International Journal of Social Science, 2(3), 93-106.

David, J. O. (2013). The root causes of terrorism: An appraisal of the socio-economic determinants of Boko Haram terrorism in Nigeria (Doctoral dissertation, University of KwaZulu-Natal, Pietermaritzburg).

Elden, S. (2014). The geopolitics of Boko Haram and Nigeria's 'war on terror.' The Geographical Journal, 180(4), 414-425. https://doi.org/10.1111/geoj.12120

Human Rights Watch (October, 2014). Those Terrible Weeks in their Camp, Boko Haram Violence against Women and Girls in Northeast Nigeria. Human Rights m, jjjjjAAQWatch. Retrieved on 08/12/2019 from: http://features.hrw.org/features/HRW 2014 report/Those Terrible Weeks in Their Camp/assets/nigeria1014web.pdf

Ikenga, F. A., \& Efebeh, V. (2013). Book Haram; a new wave of terrorist movement in Nigeria. Warri: Grace Communications International.

Isichei, E. (1987). The Maitatsine risings in Nigeria 1980-85: A revolt of the disinherited. Journal of Religion in Africa, 17(3), 194-208. https://doi.org/10.1163/157006687X00136

Jackson, B. A. (2006). Groups, networks, or movements: A command-and-control-driven approach to classifying terrorist organizations and its application to Al Qaeda. Studies in Conflict \& Terrorism, 29(3), 241-262. https://doi.org/10.1080/10576100600564042 
Lyman, P. N., \& Morrison, J. S. (2004). The terrorist threat in Africa. Foreign Affairs, 75-86. https://doi.org/10.2307/20033830

Madu, V. (2014). The concept of amalgamated security community in international relations: The case of Nigeria (Doctoral dissertation, University of Ghana).

Maiangwa, B., \& Agbiboa, D. (2014). Why Boko Haram kidnaps women and young girls in North-Eastern Nigeria. Conflict Trends, 2014(3), 51-56.

Maiangwa, B., \& Amao, O. B. (2015). Daughters, brides, and supporters of the Jihad: Revisiting the gender-based atrocities of Boko Haram in Nigeria. African Renaissance, 12(2), 117-144.

National Consortium for the Study of Terrorism and Responses to Terrorism (START) (2016). Global Terrorism Database [Data file]. Retrieved from: https://www.start.umd.edu/gtd

Nsude, I. (2016). Perception of Goodluck Ebele Jonathan's conceding speech after 2015 presidential elections implication for democracy in Nigeria. International Journal of Innovative Research and Development. ISSN 2278$0211,5(1)$.

Nwogwugwu, N., Emmanuel, A. O., \& Egwuonwu, C. (2012). Militancy and insecurity in the Niger Delta: Impact on the inflow of foreign direct investment to Nigeria. Kuwait Chapter of Arabian Journal of Business and Management Review, 2(1), 23-37.

Obi, C. K. (2015). Challenges of insecurity and terrorism in Nigeria: Implication for national development. Nigerian Criminology Journal, 9(4), 6.

Okpaga, A., Chijioke, U. S., \& Eme, O. I. (2012). Activities of Boko Haram and insecurity question in Nigeria. Arabian Journal of Business and Management Review (OMAN Chapter), 1(9), 77. https://doi.org/10.12816/0002163

Olalekan, A. (2012). Boko Haram: Jonathan fires Azazi, defence minister. Saturday Punch, Lagos, June 23, 7.

Omede, A. J. (2011). Nigeria: Analyzing the security challenges of the Goodluck Jonathan administration. Canadian social science, 7(5), 90.

Onapajo, H., \& Uzodike, U. O. (2012). Boko Haram terrorism in Nigeria: Man, the state, and the international system. African Security Review, 21(3), 24-39. https://doi.org/10.1080/10246029.2012.687693

Onuoha, F. C., \& George, T. A. (2015). Boko Haram's use of female suicide bombing in Nigeria. Aljazeera Centre for Studies, 3.

Osita-Njoku, A., \& Chikere, P. (2015). Consequences of Boko Haram terrorism on women in Northern Nigeria. Applied Research Journal, 1(3), 101-107.

Sjoberg, L., \& Gentry, C. E. (Eds.). (2011). Women, gender, and terrorism. University of Georgia Press.

Solomon, H. (2012). Counter-terrorism in Nigeria: Responding to Boko Haram. The RUSI Journal, 157(4), 6-11. https://doi.org/10.1080/03071847.2012.714183

Steward, S. (2015). An Unprecedented Use of Female Suicide Bombers. Stratfor, October, 23. Retrieved on 08/19/2019 from: https://www.crisisgroup.org/africa/west africa/nigeria/what-would-make-woman-go-back-boko-haram-despair

White, J. R. (2004). Defending the homeland: Domestic intelligence, law enforcement, and security. Wadsworth/Thomson Learning.

Yahaya, A. (2015). Analysis of the economics of terrorism in Nigeria: Boko Haram and Movement for Emancipation of the Niger Delta in perspective (Doctoral dissertation, Eastern Mediterranean University).

Zenn, J., Barkindo, A., \& Heras, N. A. (2013). The Ideological Evolution of Boko Haram in Nigeria: Merging local Salafism and international jihadism. The RUSI Journal, 158(4), 46-53. https://doi.org/10.1080/03071847.2013.826506

Zenn, J., \& Pearson, E. (2014). Women, Gender and the evolving tactics of Boko Haram. Journal of terrorism research. https://doi.org/10.15664/jtr.828 
i. The categories include MEND, Boko Haram, Niger Delta People's Volunteer Force, Urhoho Revolutionary Council, Fulani Militants, Niger Delta Liberation Force, Delta Democratic Militia, Ansaru, Gunmen, Unaffiliated Individuals, Muslim Fundamentalists, Civilian Joint Task Force, Ombatse Cult, Odua People's Congress, Tarok Militia, People's Democratic Party, Biafra Zionist Movement, Tiv Militia, Urhobo Gbagbako, Tribesmen, Islamic Movement, and Unknown.

ii The concept of Salafism is derived from al-salaf al-sālih ("the pious predecessors"). Salafism is usually designating the first three generations of Muslims, according to a tradition (hadith) of the Prophet. The basic idea of Salafism consists of following Muhammad and the pious predecessors as closely as possible.

\section{Copyrights}

Copyright for this article is retained by the author(s), with first publication rights granted to the journal.

This is an open-access article distributed under the terms and conditions of the Creative Commons Attribution license which permits unrestricted use, distribution, and reproduction in any medium, provided the original work is properly cited. 